\title{
MORPHOLOGY OF THE FIRST ZOEA OF THE SHAMEFACED CRAB CALAPPA GRANULATA (LINNAEUS, 1758) (BRACHYURA, CALAPPIDAE) OBTAINED IN THE LABORATORY
}

\author{
G. Guerao (*), P. Abelló (**) and P. Torres $(* * *)$
}

\begin{abstract}
The first zoeal stage of the calappid crab Calappa granulata is described and illustrated from laboratory-reared material obtained from an ovigerous female captured in the western Mediterranean. The morphology of this larval stage is clearly different from previous description from plankton-collected specimens attributed to this species. The present stage is compared with those previously described from other species of the genus Calappa.

Keywords: Crustacea, Decapoda, Brachyura, Calappidae, Calappa granulata, larval development, zoea.
\end{abstract}

\section{RESUMEN}

Morfología del la primera zoea del cangrejo Calappa granulata (Linnaeus, 1758) (Brachyura, Calappidae) obtenida en el laboratorio

En el presente trabajo se describe el primer estadio larvario del cangrejo Calappa granulata. Las larvas se obtuvieron a partir de una hembra ovígera capturada en el Mediterráneo occidental. La morfología de la primera zoea es claramente diferente a la anterior descripción realizada a partir de ejemplares obtenidos en el plancton, y que fue atribuida a $C$. granulata. La primera zoea de esta especie es comparada con la de otras especies descritas del género Calappa.

Palabras clave: Crustacea, Decapoda, Brachyura, Calappidae, Calappa granulata, desarrollo larvario, zoea.

\section{Introduction}

Knowledge on the larval stages of calappid crabs is limited and fragmentary (Rice, 1980; Stevcic, 1983). There are only a few papers concerning the larval development of calappid crabs and most of them deal only with the zoeal or prezoeal stages (Lebour, 1944; Raja Bai, 1959; Motoh,
1977; Terada, 1987; Seridji, 1993; GonzálezGordillo, 1994; Taishaku \& Konishi, 1995). Most of the authors which have tried to rear larvae of crabs of this family have found serious difficulties in rearing them, probably related with feeding (Taishaku \& Konishi, 1995).

Calappa granulata (Linnaeus, 1758) is a sublittoral species known from the Mediterranean Sea

\footnotetext{
* Departament de Biologia Animal (Artròpodes), Facultat de Biologia, Universitat de Barcelona, Av. Diagonal 645, 08028 Barcelona, Spain.

** Institut de Ciències del Mar (CSIC), Passeig Joan de Borbó s/n, 08039 Barcelona, Spain.

*** Centro Oceanográfico de Málaga (IEO), Puerto Pesquero s/n, 29640 Fuengirola (Málaga), Spain.
} 
and eastern Atlantic waters from Portugal to Mauritania, including the Azores, Madeira, and the Cape Verde Islands (Zariquiey-Álvarez, 1968; Manning \& Holthuis, 1981). It lives on sandy mud and muddy detritus at depths of between 13 and 400-700 m (Manning \& Holthuis, 1981; Abelló et al., 1988; García-Raso, 1984).

The prezoeal stage of Calappa granulata was obtained in the laboratory and described by González-Gordillo (1994). Seridji (1993) described and figured a first stage zoea from Mediterranean plankton samples collected off the Algerian coast, which was attributed the family Calappidae and, with some doubts, to the species $C$. granulata. Guerao et al. (1998) described the megalopa and first juvenile stage of $C$. granulata obtained from a megalopa collected in a plankton sample and subsequently reared in the laboratory.

The present paper aims to describe the morphology of the first zoeal stage of Calappa granulata and to compare its larval features with those known for other species of the genus.

\section{Material and methods}

An ovigerous female Calappa granulata, 65.9 $\mathrm{mm}$ carapace width, with eggs in an early stage of development, was collected by trawling on muddy bottoms off Cartagena $\left(37^{\circ} 30.65 \mathrm{~N}, 1^{\circ} 09.49 \mathrm{~W}\right.$, western Mediterranean) from a depth of 184-187 m on the 19th May 1997. Sampling was performed within the frame of the EU demersal fisheries research program "MEDITS" on board B/O "Cornide de Saavedra".

The crab was placed in an aquarium $(60 \times 35 \times$ $30 \mathrm{~cm})$ on board the ship containing well-aerated sea water at a salinity of approx. 37.5 and kept at 17 $\pm 1^{\circ} \mathrm{C}$. The crab was transported to the laboratory and kept at $15 \pm 1^{\circ} \mathrm{C}$. Hatching took place on the 23rd June 1997. The first zoeae were placed in both mass culture and compartmented boxes and freshly hatched Artemia nauplii were provided. Specimens zoeae were preserved in $7 \%$ buffered formalin. A high mortality followed and no larvae reached the second zoeal stage.

An Olympus phase contrast microscope was used in the dissection and observation of the setal formula of the appendages. Measurements were taken with a M5 Wild binocular microscope equipped with an ocular micrometer, and are based on measurements of 5 individuals. All drawings were made with the aid of a camera lucida. The following measurements were taken: distance from base to tip of dorsal spine (DS); distance between tips of dorsal and rostral spines (TL); carapace length, from between eyes to the posterio-lateral margin of the carapace (CL); total width, distance between the tips of lateral spines (TW). Larval description followed the basic malacostracan body pattern (Clark et al., 1998).

The adult female crab of the present study was deposited in the Biological Collections of Reference of the Institut de Ciències del Mar (CSIC) in Barcelona (Registration Number: ICMD 086/1998).

\section{Results}

Size. $\mathrm{DS}=0.70-0.77 \mathrm{~mm} ; \mathrm{CL}=0.55 \mathrm{~mm} ; \mathrm{TL}=$ $1.70-1.78 \mathrm{~mm} ; \mathrm{TW}=1.03-1.10 \mathrm{~mm}$.

Carapace (Fig. 1A, B, C, D). Dorsal, rostral and lateral spines well developed; dorsal spine slightly curved; rostral spine slightly curved with 4-6 spinules on its surface (Fig. 1D); lateral spines slightly curved with 4-6 spinules (Fig. 1C). One minute seta between the basis of the dorsal and lateral spines; without setae on ventral margin.

Antennule (Fig. 1G). Uniramous; endopod absent; exopod unsegmented with 3 terminal aesthetascs and one seta.

Antenna (Fig. 1H). Exopod less than half (1/6) the length of the spinous process, with one long and one short setae; spinous process with small spinules on the surface of the distal half.

Mandible. Incisor and molar processes well developed; mandibular palp absent.

Maxillule (Fig. 2A). Coxal endite with 7 setae; basial endite with 5 setae; endopod 2-segmented, with 4 terminal and 2 sub-terminal setae on the distal segment.

Maxilla (Fig. 2B). Coxal endite bilobed with $5+3$ setae; basial endite bilobed with $4+4$ setae; endopod bilobed with $2+5$ terminal setae; exopod (scaphognathite) margin with 4 setae and a distal stout process.

First maxilliped (Fig. 2C). Basis with 8 setae arranged 2,2,2,2; endopod 5-segmented with $2,1,0,2,4+1$ setae, respectively; exopod incompletely 2 -segmented, distal segment with 4 long terminal plumose natatory setae.

Second maxilliped (Fig. 2D). Basis with 4 setae; endopod 3-segmented with 1,1,3 setae, respectively; exopod incipiently 2 -segmented, distal segment with 4 long terminal plumose natatory setae.

Abdomen (Fig. 1A, E). Five somites; somites 2 and 3 with 1 pair of lateral processes, those on the 


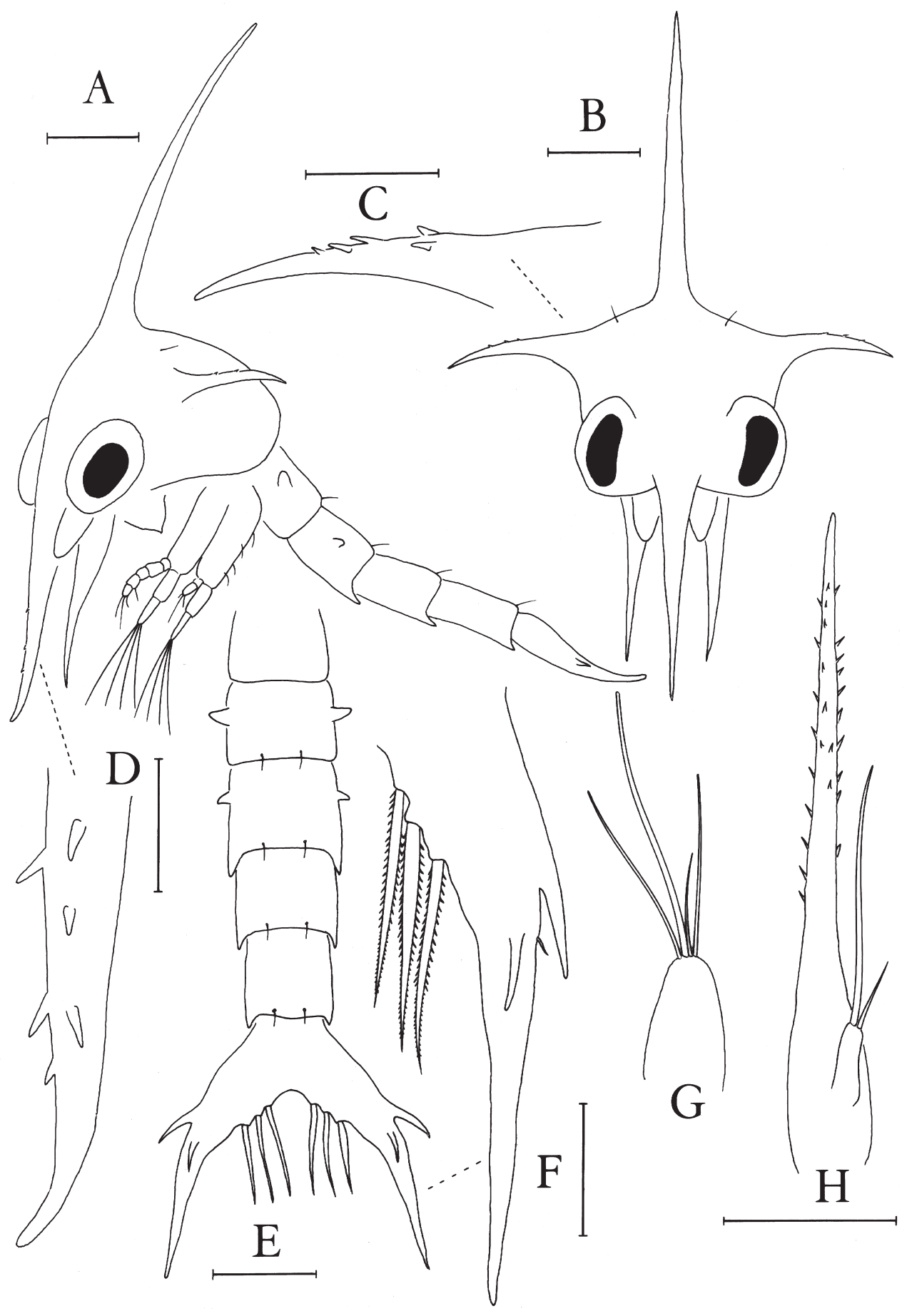

Fig. 1.- Calappa granulata, first zoea. (A) lateral view; (B) frontal view; (C) lateral spine; (D) rostral spine; (E) abdomen, dorsal view; $(F)$ half of telson, enlarged; $(G)$ antennule; $(H)$ antenna. Scale bars of $A, B$ and $E=0.2 \mathrm{~mm}$; scale of C, D, and F-H = $0.1 \mathrm{~mm}$.

Fig. 1.-Calappa granulata, primera zoea. (A) visión lateral; (B) visión frontal; (C) espina lateral; (D) espina rostral; (E) abdomen, visión dorsal; (F) ampliación del telson; $(\mathrm{G})$ anténula; $(\mathrm{H})$ antena. Escala de A, B i E = 0,2 mm; escala de C, D, i F-H = 0,1 mm. 


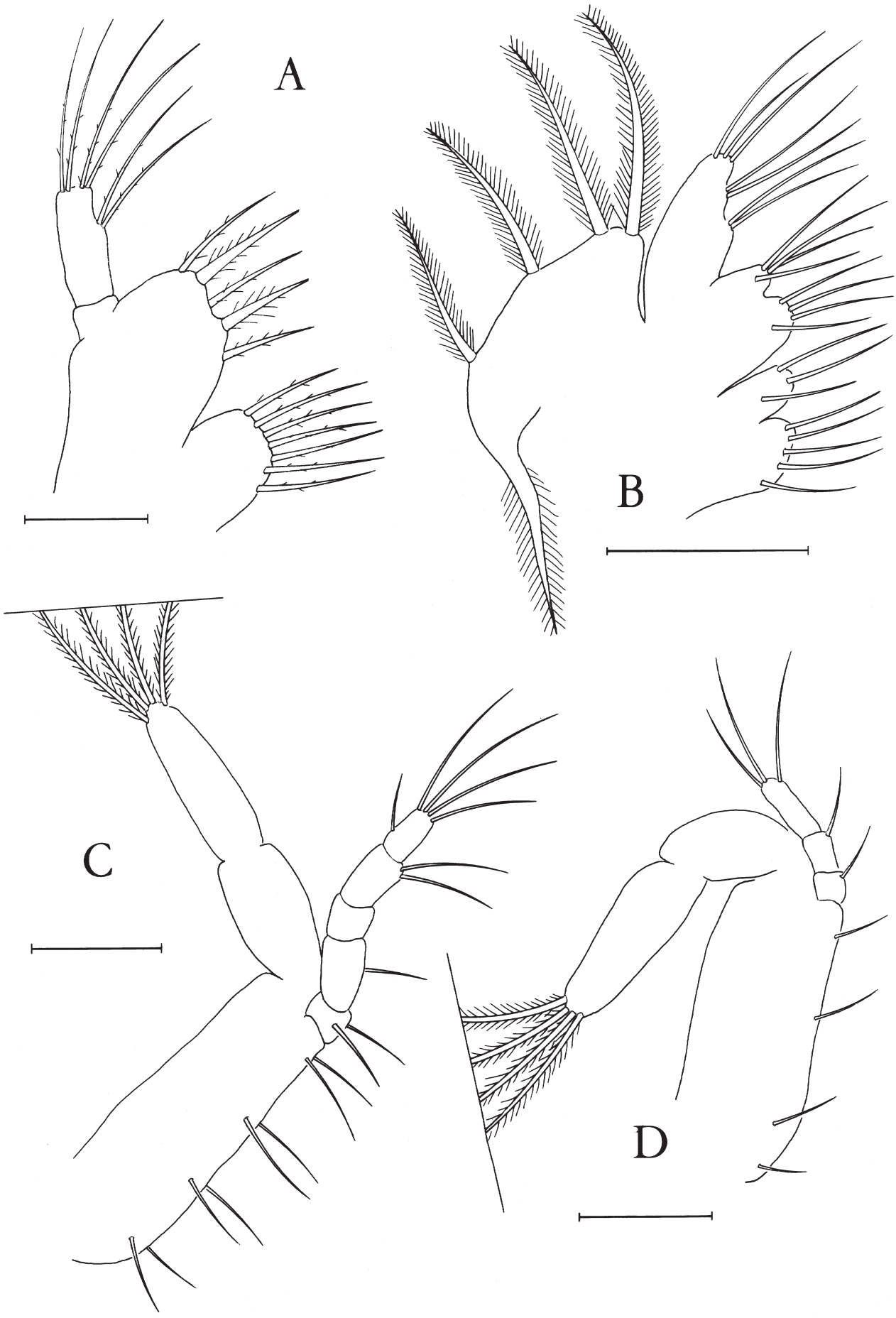

Fig. 2.-Calappa granulata, first zoea. (A) Maxillule; (B) maxilla; (C) 1st maxilliped; (D) 2nd maxilliped. Scale of $A=0.05$ $\mathrm{mm}$; scale of $\mathrm{B}-\mathrm{D}=0.1 \mathrm{~mm}$.

Fig. 2.-Calappa granulata, primera zoea. (A) Maxílula; (B) maxila; (C) maxilípedo 1; (D) maxilípedo 2. Escala de A=0,05 $\mathrm{mm}$; escala de $\mathrm{B}-\mathrm{D}=0,1 \mathrm{~mm}$. 
Table 1.- Morphological differences in the first stage zoeas of Calappa granulata (Linnaeus, 1758); C. japonica Ortmann, 1892; C. gallus (Herbst, 1803); C. lophos (Herbst, 1782) and C. philargius (Linnaeus, 1758). $S=$ setae, $A=a e s t h e t a s c s$.

Tabla 1.- Diferencias morfológicas en el primer estadio de zoea de Calappa granulata (Linnaeus, 1758); C. japonica Ortmann, 1892; C. gallus (Herbst, 1803); C. lophos (Herbst, 1782) y C. philargius (Linnaeus, 1758). S= setas, $A=$ astatecas.

\begin{tabular}{|c|c|c|c|c|c|c|}
\hline $\begin{array}{l}\text { Species } \\
\text { Reference }\end{array}$ & $\begin{array}{l}\text { C. japonica } \\
\text { Taishaku \& Konishi (1995) }\end{array}$ & $\begin{array}{l}\text { C. gallus } \\
\text { Taishaku \& Konishi (1995) }\end{array}$ & $\begin{array}{l}\text { C. lophos } \\
\text { Terada }(1987) \\
\text { Raja Bai }(1959)^{\star}\end{array}$ & $\begin{array}{l}\text { C. philargius } \\
\text { Terada }(1987) \\
\text { Motoh }(1977)^{\star}\end{array}$ & $\begin{array}{l}\text { C. granulata } \\
\text { Present paper }\end{array}$ & $\begin{array}{l}\text { C. granulata? } \\
\text { Seritji (1993) }\end{array}$ \\
\hline \multicolumn{7}{|l|}{ Morphometrics: } \\
\hline $\mathrm{DS}(\mathrm{mm})$ & $?$ & $?$ & $0.466^{*}$ & $?$ & $0.70-0.77$ & 0.45 \\
\hline $\mathrm{TL}(\mathrm{mm})$ & $1.48-1.78$ & $1.28-1.46$ & $\begin{array}{c}0.95 \\
1.066^{*}\end{array}$ & $\begin{array}{c}0.93 \\
1.20-1.30^{*}\end{array}$ & $1.70-1.78$ & 2.20 \\
\hline TW (mm) & $1.02-1.18$ & $0.84-0.98$ & $?$ & $0.72-0.75^{*}$ & $1.03-1.10$ & $?$ \\
\hline Antennule $(\mathrm{A}+\mathrm{S})$ & 4 & 4 & 3 & $\begin{array}{c}3 ? \\
2+1^{*}\end{array}$ & 4 & $?$ \\
\hline $\begin{array}{l}\text { Maxillule: } \\
\text { endopod (S) }\end{array}$ & 0,6 & 0,6 & 0,6 & $\begin{array}{l}0,6 \\
1,4^{*}\end{array}$ & 0,6 & 1,6 \\
\hline basis (S) & 5 & 5 & 5 & $6^{\star}$ & 5 & 5 \\
\hline \multicolumn{7}{|l|}{ Maxilla: } \\
\hline $\operatorname{coxa}(\mathrm{S})$ & $5+3$ & $5+3$ & $5+3$ & $\begin{array}{l}5+3 \\
5+2^{*}\end{array}$ & $5+3$ & $5+4$ \\
\hline scaphognathite (S) & 4 & 4 & 4 & 4 & 4 & $?$ \\
\hline $\begin{array}{l}\text { Maxilliped 1: } \\
\text { endopod }(\mathrm{S}) \\
\text { basis }(\mathrm{S})\end{array}$ & $\begin{array}{c}2,1,0,2,5 \\
2,2,2,2\end{array}$ & $\begin{array}{c}2,1,0,2,5 \\
2,2,2,2\end{array}$ & $\begin{array}{c}2,1,0,2,5 \\
2,2,2,2\end{array}$ & $\begin{array}{c}2,1,0,2,5 \\
2,2,2,2\end{array}$ & $\begin{array}{c}2,1,0,2,5 \\
2,2,2,2\end{array}$ & $\begin{array}{c}3,2,1,2,5 \\
1,1,2,3\end{array}$ \\
\hline $\begin{array}{l}\text { Maxilliped 2: } \\
\text { endopod (S) }\end{array}$ & $1,1,3$ & $1,1,3$ & $1,1,3$ & $1,1,3$ & $1,1,3$ & $1,1,5$ \\
\hline
\end{tabular}

third somite smaller; postero-lateral processes on somites 3-5; somites $2-5$ with 1 pair of postero-dorsal setae; pleopods absent.

Telson (Fig. 1E, F). Each telson fork with a well developed dorsal and lateral spine, and a very minute and vestigial lateral spine observed in most, not all, the zoeae studied; inner margin with 3 pairs of plumodenticulate setae, separated by a shallow median notch; setules of plumodenticulate setae smaller on the distal part.

\section{Discussion}

The morphology of the first zoea of Calappa granulata is very similar to that of other described species of the genus (see Table 1), but differs widely from the larva described by Seridji (1993). Thus, the zoea I described in the present paper does not bear denticles nor spicules on the dorsal spine or on the carapace. Also, the second lateral spine of the telson is vestigial, very minute, in C. granulata. The present zoeae are also smaller (TL: 1.70-1.78 $\mathrm{mm}$ vs $2.20 \mathrm{~mm})$. Other important differences affect the setation of the appendages (Table 1), such as the basal segment of the endopod of the maxillule, which lacks the seta figured by Seridji and is also lacking in all the rest of first zoeae of the genus Calappa described to date. The larva described by Seridji also differs widely in the setation of the maxillipeds and of the coxa of the maxilla (Table 1). All these differences lead us to conclude that Seridji's larva most probably does not belong to the genus Calappa.

\section{ACKNOWLEDGEMENTS}

We wish to thank all participants in the cruise MEDITS ES-97 on board B/O "Cornide de Saavedra", and especially Drs. L. Gil de Sola and D. Lloris for their support. This piece of research was performed within the frame of the EU research program "MEDITS" (DG XIV: MED/93/018).

\section{References}

Abelló, P., Valladares, F. J. \& Castellón, A., 1988. Analysis of the structure of decapod crustacean assemblages off the Catalan coast (North-West Mediterranean). Marine Biology, 98: 39-49. 
Clark, P. F., Calazans, D. K. \& Pohle, G. W., 1998. Accuracy and standardization of brachyuran larval descriptions. Invertebrate Reproduction and Development, 33: 127-144.

GARCÍA-RASO, E., 1984. Brachyura of the coast of Southern Spain (Crustacea, Decapoda). Spixiana, 7: 105-113.

GonzÁlez-Gordillo, J. I., 1994. Descripción de los estadios de prezoea en Cycloes cristata (Brulle, 1837) y Calappa granulata (Linnaeus, 1758) (Decapoda, Brachyura, Calappidae). Boletín del Instituto Español de Oceanografia, 10(1): 33-39.

Guerao, G., Abelló, P. \& Cartes, J., 1998. Morphology of the megalopa and first crab instar of the Shamefaced Crab Calappa granulata (Crustacea, Brachyura, Calappidae). Miscel·lània Zoològica, 21: $37-47$

Lebour, M. V., 1944. Larval crabs from Bermuda. Zoologica, 29: 113-128.

Manning, R. B. \& Holthuis, L. B., 1981. West African brachyuran crabs (Crustacea: Decapoda). Smithsonian Contributions to Zoology, 306: 1-379.

Мотон, Н., 1977. Note: larvae of decapod crustacea of the Philippines. II. Laboratory-hatached first zoea of box crab. Philippine agriculturist, 60: 345-350.

RAJA BAI, K. G., 1959. Studies on the larval development of Brachyura III: Development of Calappa lophos (Herbst) and Matuta lunaris Forskal (Crustacea; Brachyura). Journal of the Zoological Society of India, 11: 65-72.
Rice, A. L., 1980. Crab zoeal morphology and its bearing on the classification of the Brachyura. Transactions of the Zoological Society of London, 35: 271-424.

SERIDJI, R., 1993. Descriptions of some planktonic larvae of the Calappidae (Crustacea, Decapoda, Brachyura). Journal of Plankton Research, 15: 437453.

STEvcic, Z., 1983. Revision of the Calappidae. Australian Museum Memories, 18: 165-171.

TAishakU, H. \& Konishi, K., 1995. Zoeas of Calappa species with special reference to larval characters of the family Calappidae. Zoological Science, 12: 649654

TERADA, M., 1987. Zoeal forms of 14 species of crabs from the Enshunada. Research Crustacea, 16: 93120

ZARiQuieY-ÁlvareZ, R., 1968. Crustáceos decápodos ibéricos. Investigación Pesquera, 32: 1-510.

Recibido, el 12-III-1999

Aceptado, el 22-VI-1999

Publicado, el 15-XII-1999 